\title{
Changes of Tyrosine Phosphorylation in Liver and Kidney of Polycystic Ovarian Rats Induced by Letrozole
}

\author{
Cambios de Fosforilación de Tirosina en Hígado y Riñón \\ de Ratas Ováricas Poliquísticas Inducidas por Letrozol
}

\author{
Arada Chaiyamoon ${ }^{1}$; Sudtida Bunsueb ${ }^{1}$ \& Sitthichai Iamsaard ${ }^{1,2}$
}

CHAIYAMOON, A.; BUNSUEB, S. \& IAMSAARD, S. Changes of tyrosine phosphorylation in liver and kidney of polycystic ovarian rats induced by letrozole. Int. J. Morphol., 38(4):919-923, 2020.

SUMMARY: Letrozole (Letro) is a drug commonly used for breast cancer treatment since it can decrease estrogen level. In experimental animal, the Letro has been used to induce the polycystic ovarian syndrome (PCOS) model. Tyrosine phosphorylation (TyrPho) is an essential process in various biological functions both normal and abnormal conditions especially reproduction. Although some side effects of Letro are reported, the alterations of TyrPho responsible for liver and kidney functions have never been demonstrated. In this study, the blood serum, liver, and kidney of control and PCOS rats induced with Letro (orally, $1 \mathrm{mg} / \mathrm{KgBW}$ ) for consecutive 21 days were used to determine the serum biochemical components and to investigate the TyrPho expression using western blot analysis. Histopathology of such tissues was observed by Masson's trichrome staining. The results showed that Letro did not affect histological structures but significantly increased the serum levels of urea nitrogen, cholesterol, triglyceride, HDL, LDL, ALT, AST, and alkaline phosphatase. Additionally, the TyrPho protein expressions of 32 and $27 \mathrm{kDas}$ in liver and of 55 and $43 \mathrm{kDas}$ in kidney were increased while of a kidney $26 \mathrm{kDa}$ was decreased as compared to those of control. In conclusion, this recent study indicated that the changes of TyrPho proteins in liver and kidney induced with Letro associated with their functions by alteration of serum biochemical levels.

KEY WORDS: Letrozole; Tyrosine phosphorylation; Liver; Kidney; Rats.

\section{INTRODUCTION}

Tyrosine phosphorylation (TyrPho) is a biological process which is adding of a phosphoryl group to tyrosine residual of protein structure. Consequently, the TyrPho proteins are important to control various cellular mechanisms especially in eukaryotes including cell proliferation, differentiation, and cell death (Hunter, 1987; Ullrich \& Schlessinger, 1990; Hagar et al., 1997). It has been reported that the multiple intracellular signaling pathways in liver regeneration are regulated by tyrosine phosphorylation ( $\mathrm{Pa}-$ gano et al., 2012). This process is also shown to involve in induction of kidney tumor (Narayan \& Roy, 1992). Indeed, the expressions of TyrPho proteins were found in differentiation of both normal and carcinoma cells (Paul \& Mukhopadhyay, 2004). In current researches especially in reproductive system, the TyrPho proteins have been localized in testis (Arun et al., 2016a), epididymis (Sawatpanich et al., 2018), and seminal vesicle (Tongpan et al., 2019) of rats. It was well known that those protein expressions are changed when animals are treated with chemicals or being diseases such as stress and diabetic mellitus. Moreover, the phosphorylation rates of tyrosine protein were demonstrated to be increased in apoptotic neural cell death (Chromy et al., 2000).

Letrozole (Letro) or Femara is a non-steroidal aromatase inhibitor clinically used to reduce estrogen level via steroidal synthesis inhibition for breast cancer treatment (He \& Ma, 2016) and to delay cancer cell metastasis (Wang et al., 2016). The Letro was also used for gastric cancer treatment (El Hadi, 2011). As it has property like aromatase inhibitor, Letro commonly used to induce polycystic ovary syndrome (PCOS) in the animal model in study of its mechanism and prevention for PCOS infertile patients. Interestingly, it has been reported that an aromatase inhibitor letrozole is not superior to the clomiphene in patients with PCOS (Guang, 2018). Many women with PCOS are associated with an increased risk of metabolic syndrome, obesity, and type 2 diabetes (Torres et al., 2019). In previous study, the effects of aromatase inhibitor letrozole on tyrosine phosphorylated protein expression in liver and kidney have

\footnotetext{
${ }^{1}$ Department of Anatomy, Faculty of Medicine, Khon Kaen University, Khon Kaen, 40002, Thailand.

${ }^{2}$ Research Institute for Human High Performance and Health Promotion (HHP \& HP), Khon Kaen University, Khon Kaen, 40002, Thailand.
} 
never been demonstrated. We therefore aimed to investigate the alterations of liver and renal function parameters and of their tissue TyrPho expressions in rats induced with Letro.

\section{MATERIAL AND METHOD}

Animals and experimental design: The Wistar female rats (180-200 g) were purchased from the Nomura Siam International Co., Ltd., Pathumwan, Bangkok, Thailand before transferring to the Animal Laboratory Unit, Faculty of Medicine, Khon Kaen University, Thailand. This experiment was approved by the Animal Ethics Committee of Faculty of Medicine, Research Affaires, Khon Kaen University (Record No. AEMDKKU 011/2019). After acclimatization for 7 days, the animals $(n=7$, each group) were divided into 2 groups; control group orally received carboxymethyl cellulose solution (Union science trading, Thailand) and letrozole treated group was induced for PCOS by oral administration with letrozole (Femora ${ }^{\circledR}$, Inhouse pharmacy, USA), $1 \mathrm{mg} / \mathrm{KgBW}$ for consecutive 21 days (Kafali et al., 2004).

Sample collection and histopathological study: After euthanasia and abdominal wall opening, both liver and kidney were collected and fixed in $10 \%$ formalin diluted with PBS, $\mathrm{pH} 7.4$ for $48 \mathrm{~h}$. The fixed specimens were histologically processed by using automatic tissue processor at the Department of Pathology, Faculty of Medicine, Khon Kaen University. Subsequently, the infiltrated samples were embedded in paraffin and sectioned with 5-7 mm thickness. Then, the paraffin sections were stained with Masson trichrome (catalogue no. HT15, Sigma-Aldrich) to investigate the thickness of the collagen fibers and histological changes in liver and kidney tissues. All microphotographs were captured by using Nikon light ECLIPSE E200 microscope with a DKM1200 digital camera.
Serum collection and biochemical assays: Blood from all animals was collected from the left ventricle by cardiac puncture and centrifuged at $12000 \mathrm{rpm}, 4{ }^{\circ} \mathrm{C}$ for $10 \mathrm{~min}$ to separate the serum from blood cells. The serum was sent to Clinical Chemistry Unit, Srinagarind Hospital, Faculty of Medicine, KKU, Thailand, for biochemical analyses of blood glucose level and liver and renal function parameters.

SDS-PAGE and western blot: Liver and kidney were homogenized with RIPA buffer (Cell Signaling Technology Inc., USA) containing protease inhibitor cocktails and centrifuged at $14,000 \mathrm{rpm}$ at $4{ }^{\circ} \mathrm{C}$ for $10 \mathrm{~min}$. Protein concentrations of the liver and kidney tissue lysates were measured using a NanoDrop ND-1000 Spectrophotometer (NanoDrop Technologies Inc., USA) at an absorbance of $280 \mathrm{~nm}$. Total protein lysate $(100 \mathrm{mg})$ was loaded and separated onto sodium dodecyl sulfate-polyacrylamide gel electrophoresis (SDS-PAGE) before staining with Coomasie blue to observe the protein profile. To study the tyrosine phosphorylated protein expression, the separated proteins were transferred onto nitrocellulose membrane. The membrane was incubated with5 \% skim-milk blocking solution and washed with $0.05 \%$ PBST. Then it was incubated with anti-phosphotyrosine primary antibody [1:2000 (v/v); Millipore Co., USA] or b-actin antibody [1:2000 (v/v) dilution; Santa Cruz Biotechnology Inc., USA] at $4{ }^{\circ} \mathrm{C}$ overnight. After that, the membrane was incubated with goat anti-mouse conjugated horseradish peroxidase (HRP) secondary antibody for $1 \mathrm{~h}$ at room temperature and washed with $0.05 \%$ PBS. In subsequence, the expression of antigen-antibody complex was detected by adding an enhanced chemiluminescence (ECL) substrate under gel doct 4 (Image Quant 400, GH Healthcare, USA).

Statistical analysis: The independent t-test was performed to analysis of the statistically significant differences $(\mathrm{P} \leq 0.05)$ between treated and control groups by using SPSS statistics 19.0 software.
Table I. Comparisons of the serum biochemical parameters between control and letrozoletreated female rats.

\begin{tabular}{lcr}
\hline Serum biochemical parameters & Control & \multicolumn{1}{c}{ Letrozole } \\
\hline Blood sugar $(\mathrm{mg} / \mathrm{dL})$ & $198.94 \pm 10.29$ & $204.50 \pm 1.19$ \\
Urea nitrogen $(\mathrm{mg} / \mathrm{dL})$ & $19.10 \pm 0.00$ & $23.70 \pm 0.08^{*}$ \\
Creatinine $(\mathrm{mg} / \mathrm{dL})$ & $0.29 \pm 0.00$ & $0.27 \pm 0.00^{*}$ \\
Cholesterol $(\mathrm{mg} / \mathrm{dL})$ & $49.40 \pm 1.67$ & $64.00 \pm 0.00^{*}$ \\
Trigly ceride $(\mathrm{mg} / \mathrm{dL})$ & $53.40 \pm 1.67$ & $67.00 \pm 0.79 *$ \\
HDL $(\mathrm{mg} / \mathrm{dL})$ & $36.05 \pm 1.25$ & $49.50 \pm 0.40^{*}$ \\
LDL $(\mathrm{mg} / \mathrm{dL})$ & $5.35 \pm 0.42$ & $8.00 \pm 0.00^{*}$ \\
ALT $(\mathrm{U} / \mathrm{L})$ & $24.70 \pm 0.84$ & $35.50 \pm 0.40^{*}$ \\
AST $(\mathrm{U} / \mathrm{L})$ & $70.75 \pm 2.09$ & $111.50 \pm 1.19^{*}$ \\
Alkaline phosphatase $(\mathrm{U} / \mathrm{L})$ & $58.75 \pm 2.09$ & $124.00 \pm 0.79^{*}$ \\
*Statistically significant difference $(\mathrm{P}<0.05)$ compared to control. Data are expressed as mean $\pm \mathrm{SD}(\mathrm{N}=5)$.
\end{tabular}

\section{RESULTS}

The results showed that all parameters of serum biochemistry except the blood sugar in the letrozole (Letro) treated animals were significantly different from those of control rats $(\mathrm{P}<0.05)$ as shown in the Table I. It was found that the serum levels of urea nitrogen, cholesterol, triglyceride, HDL, LDL, ALT, AST, and alkaline phosphatase in Letro 
group were significantly increased as compared to control (Table 1). However, only creatinine level was significantly decreased in Letro-treated animals.

In addition, it was demonstrated that the total protein profiles of lever lysates revealed by SDS-PAGE of control and Letro-treated groups were not obviously altered (Fig. 1, left panel). Interestingly, the intensities of 32 and 27 tyrosine phosphorylated proteins of liver tissue in Letro group were higher than those of control (Fig. 1, right panel).

Similar to SDS-PAGE results of the liver, no difference of the total protein profiles in kidney lysates between control

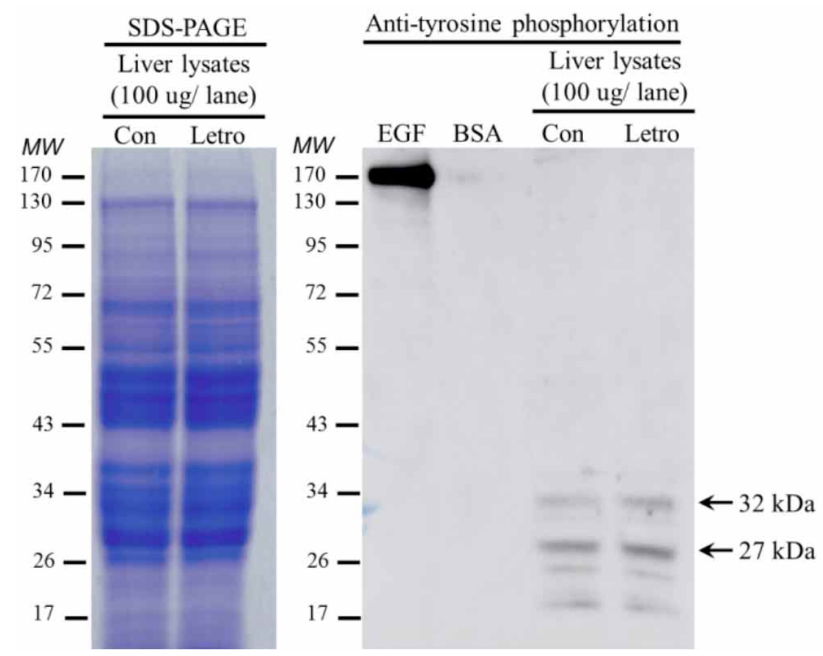

Fig.1 Showing the total protein profiles $(100 \mu \mathrm{g}$; left panel) and immuno-western bolting of tyrosine phosphorylation (right panel) in liver lysate of control and letrozole (Letro) treated group. The epididymal growth factor (EGF) and bovine serum albumin were used as positive and negative controls, respectively. and Letro-treated groups were found (Fig. 2, left panel). However, it was shown that the intensities of 55 and 43 tyrosine phosphorylated proteins of kidney tissue in Letro group were increased as compared to control (Fig. 1, right panel). However, a kidney tyrosine phosphorylated protein of $26 \mathrm{kDa}$ showed more expression in Letro-treated group.

Figure 3 showed the histology of liver and kidney stained by Masson's trichrome to observe the histopathology such as fibrotic tissue and cellular abnormality in letrozole treatment. As observed, no fibrosis and cellular damage in hepatic portal triad or in renal tubular and corpuscle were found in control and Letro-treated groups (Fig. 3)

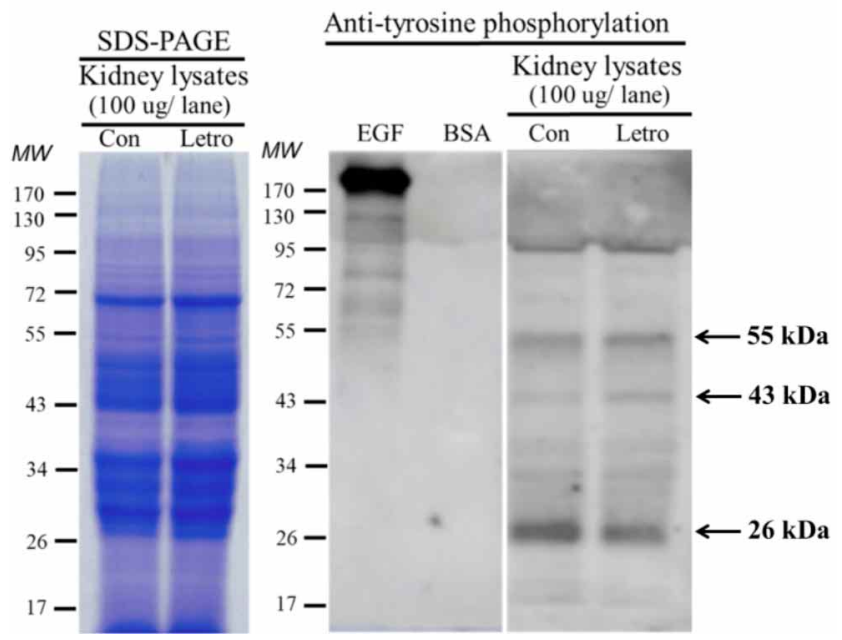

Fig 2. Showing representative SDS-PAGE of the total protein profiles $(100 \mu \mathrm{g}$; left panel) and immuno-western bolting of tyrosine phosphorylation (right panel) in kidney of control and letrozole (Letro) treated group.

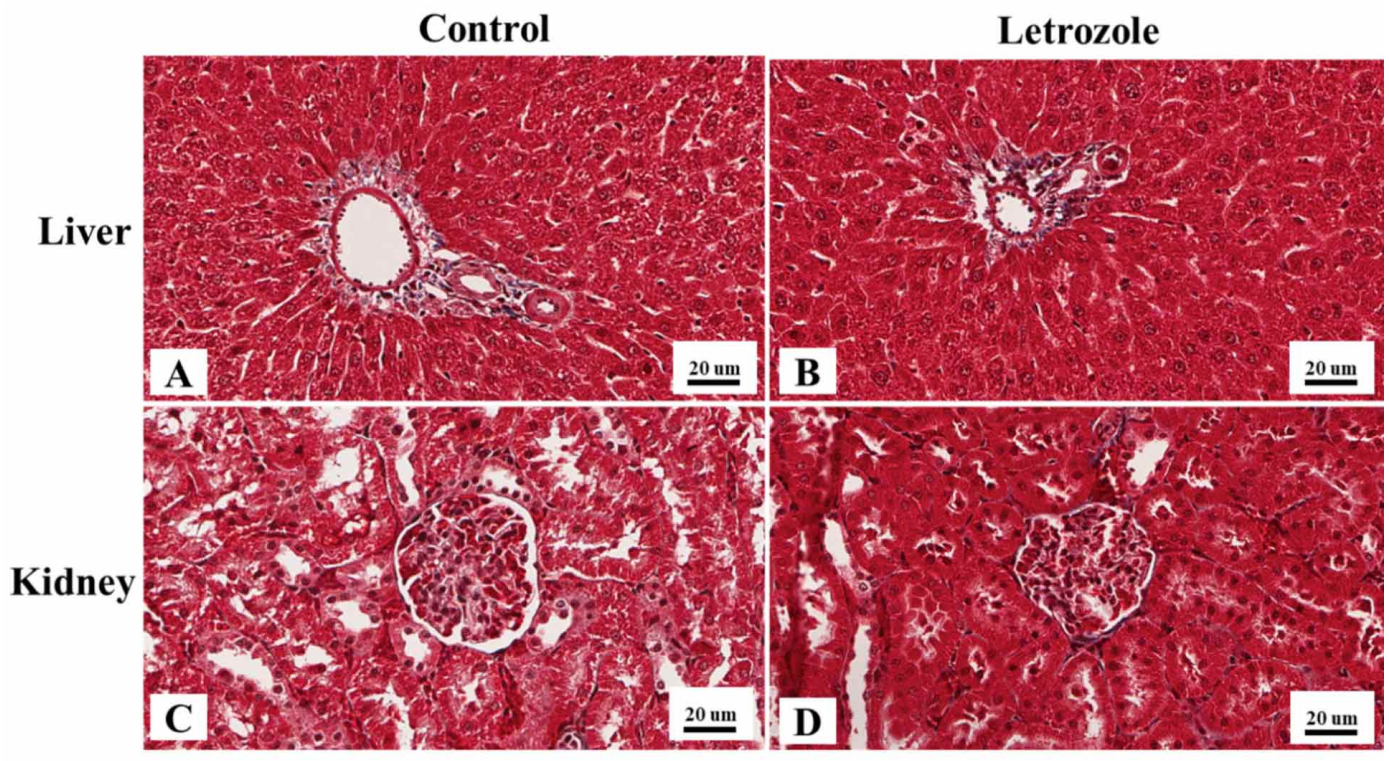

Fig. 3. Representative h i s t o lo g i c a 1 photographs of liver and kidney tissues stained by Masson's trichrome compared between the control group (A and C) and Letro-treated group (C and D). 


\section{DISCUSSION}

Herein, our results have shown that the treatment of letrozole (Letro, $1 \mathrm{mg} / \mathrm{KgBW}$ ) for consecutive 21 days) affected the most biochemical functions of blood serum. Such alterations indicate abnormality of liver and kidney functions although their histological structures were not obviously changed, including no fibrosis appearance. In fact, a dose of Letro used in this study is a common dose applied for polycystic ovarian syndrome (PCOS) induction (Kar, 2013; Palomba, 2015; Pandey et al., 2016; Tanbo et al., 2018). Indeed, the animals induced with Letro in our study show significant increase of androgen (testosterone) level and predominant polycystic follicles revealed by histology (data not shown). Therefore, it is difficult to explain whether Letro or consequence of PCOS by elevated androgen could directly affect the liver and kidney functions. Possibly, the dysfunctions of such vital organs may be caused from direct Letro interaction or excess androgen levels. Letro is known to be an aromatase inhibitor exhibiting anti-estrogenic activity which used as endocrine therapy for patients with breast cancer. Although associations between metabolic and liver adverse effects of Letro from previous works are still conflicting, our results and other have demonstrated the increase of serum lipid profiles including cholesterol, triglyceride, HDL, and LDL, respectively (Hewitt et al., 2004; Moro et al., 2010). This drug seemed not to affect the metabolic and lipid profiles in ovariectomized rats (Boutus et al., 2015) but it increased hepatic function parameters (Aydin et al., 2011). In contrast to our results, the long period of Letro treatment has been shown to have the lipid accumulation and hepatic steatosis in the liver (Hewitt et al.; Moro et al.). In the PCOS rats, we have demonstrated for the first time that Letro significantly increased the renal function parameters but did not change the uriniferous tubules. As previously reviewed, the gonadal dysfunctions are related to renal failure and liver diseases (Karagiannis \& Harsoulis, 2005). Therefore, the increase of function parameters of liver and kidney induced by Letro might be caused from both aromatase inhibition and estrogenic impairment.

Tyrosine phosphorylation (TyrPho) is an essential process involved in many physiological mechanisms such as cellular signaling pathways. Particularly, the alterations of TyrPho proteins in reproductive system have been shown to be sensitive to cancer drug treatments (Iamsaard et al., 2014; Iamsaard et al., 2017; Sukhorum \& Iamsaard, 2017; Iamsaard et al., 2018; Sawatpanich et al.; Chaichun et al., 2019; Tongpan et al.), diabetic mellitus (Yannasithinon \& Iamsaard, 2009; Sampannang et al., 2018, 2019), and stress conditions (Arun et al., 2016a,b, 2018). Currently, it has been reported that the decreased expression of a TyrPho protein in kidney induced by valproic acid, an antiepileptic drug, is associated with the increased malondialdehyde levels and renal vasodilation (Maneenin et al., 2019). Demonstrated for the first time, the expressions of many TyrPho proteins in liver and kidney of PCOS rats induced by Letro in this study were changed. It is possible that those proteins may play the important roles in regulation of functional factor parameters produced from liver and kidney. In conclusion, not only Letro can induce PCOS in rat model, it also alters the TyrPho protein in liver and kidney, resulting in increase of biochemical function parameters in blood serum.

CHAIYAMOON, A.; BUNSUEB, S. \& IAMSAARD, S. Cambios de fosforilación de tirosina en hígado y riñón de ratas ováricas poliquísticas inducidas por letrozol. Int. J. Morphol., 38 (4):919923, 2020.

RESUMEN: El letrozol (Letro) es un medicamento utilizado comúnmente para el tratamiento del cáncer de mama, debido a que puede disminuir el nivel de estrógeno. En animales de experimentación, el Letro se ha utilizado para inducir el modelo de síndrome de ovario poliquístico (PCOS). La fosforilación de tirosina (TyrPho) es un proceso esencial en diversas funciones biológicas, tanto en condiciones normales como anormales, especialmente en la reproducción. A pesar de informes que indican algunos efectos secundarios de Letro, no se han demostrado las alteraciones de TyrPho responsables de las funciones hepáticas y renales. En este estudio, el suero sanguíneo, el hígado y el riñón control y las ratas PCOS inducidas con Letro (por vía oral, $1 \mathrm{mg} / \mathrm{KgBW}$ ) durante 21 días consecutivos se usaron para determinar los componentes bioquímicos del suero y para investigar la expresión de TyrPho usando análisis de transferencia Western. La histopatología de los tejidos se observó mediante la tinción tricrómica de Masson. Los resultados mostraron que Letro no afectó las estructuras histológicas, pero aumentó significativamente los niveles séricos de urea, colesterol, triglicéridos, HDL, LDL, ALT, AST y fosfatasa alcalina. Además, las expresiones de la proteína TyrPho de 32 y 27 kDas en el hígado y de 55 y 43 kDas en el riñón aumentaron mientras que en un riñón disminuyeron $26 \mathrm{kDa}$ en comparación con el control. En conclusión, este estudio indicó que los cambios de las proteínas TyrPho en el hígado y los riñones inducidos con Letro se asociaron con sus funciones mediante la alteración de los niveles bioquímicos en suero.

PALABRAS CLAVE: Letrozol; Fosforilación de tirosina; Hígado; Riñón; Ratas.

\section{REFERENCES}

Arun, S.; Burawat, J.; Sukhorum, W.; Sampannang, A.; Maneenin, C. \& Iamsaard, S. Chronic restraint stress induces sperm acrosome reaction and changes in testicular tyrosine phosphorylated proteins in rats. Int. J. Reprod. Biomed. (Yazd.), 14(7):443-52, 2016 b. 
Arun, S.; Burawat, J.; Sukhorum, W.; Sampannang, A.; Uabundit, N. \& Iamsaard, S. Changes of testicular phosphorylated proteins in response to restraint stress in male rats. J. Zhejiang Univ. Sci. B., 17(1):21-9, 2016a.

Arun, S.; Burawat, J.; Yannasithinon, S.; Sukhorum, W.; Limpongsa, A. \& Iamsaard, S. Phyllanthus emblica leaf extract ameliorates testicular damage in rats with chronic stress. J. Zhejiang Univ. Sci. B., 19(12):948$59,2018$.

Aydin, M.; Oktar, S.; Ozkan, O. V.; Alçin, E.; Oztürk, O. H. \& Nacar, A. Letrozole induces hepatotoxicity without causing oxidative stress: the protective effect of melatonin. Gynecol. Endocrinol., 27(4):209-15, 2011.

Chaichun, A.; Burawat, J.; Arun, S.; Tongpan, S.; Kanla, P.; Sawatpanich, T. \& Iamsaard, S. Mimosine increases the expressions of tyrosine phosphorylated protein in mouse seminal vesicles. Int. J. Morphol., 37(4):1463-8, 2019.

Chromy, B. A., Lambert, M. P., \& Klein, W. L. Increased protein tyrosine phosphorylation in apoptotic neural cell death due to microtubule perturbations. Neurotox. Res., 2(4):357-72, 2000.

El Hadi, A.; Al-Momani, H. \& Edwards, P. An effect of letrozole on gastric cancer? J. Gastric Cancer, 11(3):180-4, 2011.

Guang, H. J.; Li, F. \& Shi, J. Letrozole for patients with polycystic ovary syndrome: A retrospective study. Medicine (Baltimore), 97(44):e13038, 2018.

Hagar, H.; Ueda, N. \& Shah, S. V. Tyrosine phosphorylation in DNA damage and cell death in hypoxic injury to LLC-PK1 cells. Kidney Int., 51(6):1747-53, 1997.

He, D. X., \& Ma, X. Clinical utility of letrozole in the treatment of breast cancer: a Chinese perspective. Onco Targets Ther, 9:1077-84, 2016.

Hewitt, K. N.; Pratis, K.; Jones, M. E. \& Simpson, E. R. Estrogen replacement reverses the hepatic steatosis phenotype in the male aromatase knockout mouse. Endocrinology, 145(4):1842-8, 2004.

Hunter, T. A thousand and one protein kinases. Cell, 50(6):823-9, 1987.

Iamsaard, S.; Burawat, J.; Kanla, P.; Arun, S.; Sukhorum, W.; Sripanidkulchai, B.; Uabundit, N.; Wattathorn, J.; Hipkaeo, W.; Fongmoon, D.; et al. Antioxidant activity and protective effect of Clitoria ternatea flower extract on testicular damage induced by ketoconazole in rats. J. Zhejiang Univ. Sci. B., 15(6):548-55, 2014.

Iamsaard, S.; Sukhorum, W.; Arun, S.; Phunchago, N.; Uabundit, N.; Boonruangsri, P. \& Namking, M. Valproic acid induces histologic changes and decreases androgen receptor levels of testis and epididymis in rats. Int. J. Reprod. Biomed. (Yazd.), 15(4):217-24, 2017.

Iamsaard, S.; Welbat, J. U.; Sukhorum, W.; Krutsri, S.; Arun, S. \& Sawatpanich, T. Methotrexate changes the testicular tyrosine phosphorylated protein expression and seminal vesicle epithelia of adult rats. Int. J. Morphol., 36(2):737-42, 2018.

Kafali, H.; Iriadam, M.; Ozardali, I. \& Demir, N. Letrozole-induced polycystic ovaries in the rat: a new model for cystic ovarian disease. Arch. Med. Res., 35(2):103-8, 2004.

Kar, S. Current evidence supporting "letrozole" for ovulation induction. $J$. Hum. Reprod. Sci., 6(2):93-8, 2013.

Karagiannis, A. \& Harsoulis, F. Gonadal dysfunction in systemic diseases. Eur. J. Endocrinol, 152(4):501-13, 2005.

Maneenin, C.; Lapyuneyong, N.; Tongpan, S.; Yannasithinon, S.; Burawat, J.; Maneenin, N.; Sukhorum, W.; Arun, S. \& Iamsaard, S. The alterations of microvasculature, tyrosine phosphorylation, and lipid peroxidation in kidney of rats treated with valproic acid. Int. J. Morphol., 37(1):6570, 2019.

Moro, L.; Arbini, A. A.; Hsieh, J. T.; Ford, J.; Simpson, E. R.; Hajibeigi, A. \& Oz, O. K. Aromatase deficiency inhibits the permeability transition in mouse liver mitochondria. Endocrinology, 151(4):1643-52, 2010.

Narayan, S. \& Roy, D. Enhanced expression of membrane phosphoproteins tyrosine phosphorylation in estrogen-induced kidney tumors. Biochem. Biophys. Res. Commun., 186(1):228-36, 1992.

Pagano, M. A.; Tibaldi, E.; Gringeri, E. \& Brunati, A. M. Tyrosine phosphorylation and liver regeneration: A glance at intracellular transducers. IUBMB Life, 64(1):27-35, 2012.
Palomba, S. Aromatase inhibitors for ovulation induction. J. Clin. Endocrinol. Metab., 100(5):1742-7, 2015.

Pandey, V.; Singh, A.; Singh, A.; Krishna, A.; Pandey, U. \& Tripathi, Y. B. Role of oxidative stress and low-grade inflammation in letrozoleinduced polycystic ovary syndrome in the rat. Reprod. Biol., 16(1):707, 2016.

Paul, M. K. \& Mukhopadhyay, A. K. Tyrosine kinase - Role and significance in Cancer. Int. J. Med. Sci., 1(2):101-15, 2004.

Sampannang, A.; Arun, S.; Burawat, J.; Sukhorum, W. \& Iamsaard, S. Testicular histopathology and phosphorylated protein changes in mice with diabetes induced by multiple-low doses of streptozotocin: An experimental study. Int. J. Reprod. Biomed. (Yazd.), 16(4):235-46, 2018.

Sampannang, A.; Arun, S.; Burawat, J.; Sukhorum, W. \& Iamsaard, S. Expression of testicular phosphorylated proteins in types 1 and 2 diabetes mellitus in mice: An experimental study. Int. J. Reprod. Biomed. (Yazd.), 17(8):567-76, 2019.

Sawatpanich, T.; Arun, S.; Tongpan, S.; Chaichun, A.; Sampannang, A.; Sukhorum, W.; Maneenin, C.; Burawat, J. \& Iamsaard, S. Localization and changes of tyrosine phosphorylated proteins and $B$ actin in epididymis of rats treated with valproic acid. Int. J. Morphol., 36(3):83540, 2018.

Sukhorum, W. \& Iamsaard, S. Changes in testicular function proteins and sperm acrosome status in rats treated with valproic acid. Reprod. Fertil. Dev., 29(8):1585-92, 2017.

Tanbo, T.; Mellembakken, J.; Bjercke, S.; Ring, E.; Åbyholm, T. \& Fedorcsak, P. Ovulation induction in polycystic ovary syndrome. Acta Obstet. Gynecol. Scand., 97(10):1162-7, 2018.

Tongpan, S.; Sukhorum, W.; Arun, S.; Sawatphanich, T. \& Iamsaard, S. Valproic acid changes the expression of tyrosine-phosphorylated proteins in rat seminal vesicle. Andrologia, 51(7):e13303, 2019.

Torres, P. J.; Skarra, D. V.; Ho, B. S.; Sau, L.; Anvar, A. R.; Kelley, S. T. \& Thackray, V. G. Letrozole treatment of adult female mice results in a similar reproductive phenotype but distinct changes in metabolism and the gut microbiome compared to pubertal mice. BMC Microbiol., 19(1):57, 2019.

Ullrich, A. \& Schlessinger, J. Signal transduction by receptors with tyrosine kinase activity. Cell, 61(2):203-12, 1990.

Wang, W.; Belosay, A.; Yang, X.; Hartman, J. A.; Song, H.; Iwaniec, U. T.; Turner, R. T.; Churchwell, M. I.; Doerge, D. R. \& Helferich, W. G. Effects of letrozole on breast cancer micro-metastatic tumor growth in bone and lung in mice inoculated with murine 4T1 cells. Clin. Exp. Metastasis, 33(5):475-85, 2016.

Yannasithinon, S. \& Iamsaard, S. Alterations of morphology and phosphorylated protein expression in the seminal vesicles of diabetic mice. Andrologia, 51(10):e13406, 2019.

\section{Corresponding authors:}

Dr. Sitthichai lamsaard \& Dr. Arada Chaiyamoon
Department of Anatomy
Faculty of Medicine
Khon Kaen University
123 Mitrapap Road
Amphoe Muang
Khon Kaen 40002
THAILAND

\section{Email: sittia@kku.ac.th aradch@kku.ac.th}

Received: 20-10-2019

Accepted: 06-02-2020 